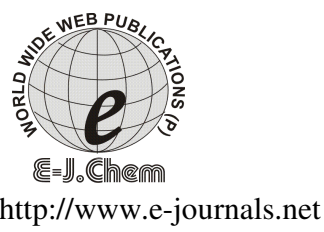

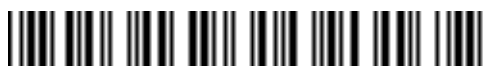

ISSN: 0973-4945; CODEN ECJHAO

E-Journal of Chemistry

Vol. 4, No. 2, pp 192-198, April 2007

\title{
Tannase Production By Aspergillus niger
}

\author{
N. LOKESWARI* and K. JAYA RAJU \\ Center for Biotechnology, \\ Department of Chemical Engineering, \\ Andhra University, \\ Visakhapatnam- 530003, \\ Email:lokeswarin@hotmail.com
}

Received 22 November 2006; Revised 29 December 2006; Accepted 6 January 2007

\begin{abstract}
A method for assay of microbial tannase (Tannin acyl hydrolase) based on the formation of chromogen between gallic acid and rhodanine is reported. Maximum Tannase production occurred in the culture broth containing $1-2 \%(\mathrm{w} / \mathrm{v})$ tannic acid and $0.05-0.1 \%(\mathrm{w} / \mathrm{v})$ glucose. The $\mathrm{pH}$, incubation period, temperature and Glucose concentration optima of Tannase production was found at $5.5,36 \mathrm{~h}, 35{ }^{\circ} \mathrm{C}$ and $0.5 \%$ respectively. These properties make the enzyme suitable for pollution control and bioprocess industry. This assay is very simple, reproducible, and very convenient, and with it Tannase activity can be measured in relation to the growth of the organism. Aspergillus niger exhibited higher enzyme activity showing about 65 mole percent conversion respectively after a $36 \mathrm{~h}$ incubation period. The assay is complete in a short time, very convenient and reproducible.
\end{abstract}

Keywords: Tannic acid, Gallic acid, Gallo tannin, Tannase, Tannin.

\section{Introduction}

Tannin acyl hydrolase commonly called tannase is produced by a number of microorganisms like fungi (Aspergillus, Penicillium, Rhizopus sp), yeast (Candida sp), and bacteria (Bacillus sp) ${ }^{1-2}$. The major commercial application of this enzyme is in the hydrolysis of gallotannin to Gallic acid, is an intermediate required for the synthesis of an antifolic antibacterial drug trimethoprim ${ }^{3}$. Tannase is extensively used in the preparation of instant tea, wine, beer, and coffee - flavored soft drinks and also as additive for detannification of food ${ }^{4}$. Purification and evaluation of the enzyme require a sensitive, reproducible, and convenient assay method. A number of chromogenic methods have been described for the assay of tannase that are not specific ${ }^{5}$. Madhavakrishan et al. reported a method for tannase assay based on the estimation of glucose liberated by incubation with the enzyme for $24 \mathrm{~h}$, which is not suitable for routine assays of the enzyme ${ }^{6}$. Iibuchi et al. described a spectrophotometric method that has been used by many workers in its original and modified forms ${ }^{1-2}$. 
This method was based on the decrease in absorbance of the substrate Tannic acid at $310 \mathrm{~nm}$. Some workers have assayed tannase by measuring gallic acid using chromatographic techniques such as gas chromatography ${ }^{7}$, or high - performance liquid chromatography ${ }^{8}$. But each method has its own limitations and most are time consuming and also require instrument sophistication. Considering this, Inoue and Hagerman, have described a method for the determination of gallotannins, which involves the formation of a chromogen between gallic acid obtained by the acid hydrolysis of gallotannis and rhodanine ${ }^{9}$. This was later adapted by ${ }^{10}$, for the assay of tannase in a ruminal bacterium. It is simple, reproducible, and with it tannase activity can be measured in relation to the growth of the organism.

The present paper, reports the production of tannase from a newly isolated Aspergillus niger in liquid culture medium by submerged fermentation technique. Some properties of tannase have also been studied.

\section{Experimental}

\section{Chemicals}

Gallotannin was bought from National Chemicals, Nutan, Gujarat, India. Tannic Acid was bought from Loba chemical Pvt. Ltd. Bombay, India. Potato sucrose agar from Himedia. Acetic acid, sodium acetate, ferric chloride, hydrochloric acid, potassium hydroxide were bought from Loba chemical Pvt. Ltd, Bomba, India. Triethanolamine, sodiumdodecyl sulphate, sulphuric acid were bought from Ranbaxy. Bovineserum albumin was bought from Sigma.

\section{Microorganism}

Aspergillus niger obtained from Institute Microbial Technology, Chandigarh was used for the present work. Aspergillus niger grows on Czapek yeast extract agar medium containing $0.01 \%$ gallotannin. It grows rapidly at room temperature $\left(25{ }^{\circ} \mathrm{C}\right)$ and at $37{ }^{\circ} \mathrm{C}$. The slant cultures were then used for further work or stored in refrigerator at $4{ }^{\circ} \mathrm{C}$.

\section{Preparation of Spore Suspension:}

$8 \mathrm{~mL}$ of sterile distilled water was taken in $50 \mathrm{~mL}$ conical flask. The mycelia of the slant cultures were scraped off in $2 \mathrm{~mL}$ of distilled water. The resulting spore suspension was mixed to obtain a uniform suspension. This suspension was then added to distilled water to give $10 \mathrm{~mL}$ of spore suspension for spore dilution.

\section{Preparation of induced inoculum}

Tannase being an adaptive enzyme, preinduced inoculum is required to be prepared. The medium used for growing fungi, Aspergillus niger was potato dextrose broth containing $0.5 \%$ gallotannin adjusted to $\mathrm{pH}$ 5.6. $50 \mathrm{~mL}$ gallotannin containing potato dextrose medium was taken, then each one is transferred to respective $250 \mathrm{~mL}$ conical flask and then sterilized. These flasks were inoculated aseptically with $2 \mathrm{~mL}$ of spore suspension prepared from the culture slants. These flasks were kept in a rotatory shaker $(160 \mathrm{rpm})$ at $32{ }^{\circ} \mathrm{C}$ for 48 $\mathrm{h}$. After $48 \mathrm{~h}$ of incubation this induced inoculum was used for subsequent studies of tannase production.

\section{Fermentation method for enzyme production}

Enzyme productin was carried out in 250-mL Erlenmeyer flasks containing 50-mL 2\% tannic acid in potato dextrose broth ( $\mathrm{pH} 5.5$ ) medium was taken in $100 \mathrm{~mL}$ conical flasks. Then it 
was sterilized and inoculated with $2 \%(\mathrm{v} / \mathrm{v})$ inoculum was added and incubated at $35{ }^{\circ} \mathrm{C}$ for $36 \mathrm{~h}$ in a rotary shaker (200-rpm). The culture supernatants obtained by filtration (through Whatman No.1 paper) were assayed periodically for tannase activity. Enzyme production has also been carried out in presence of different concentrations of glucose, incubation period, $\mathrm{pH}$, and Temparature. Growth of the organism was estimated on the basis of biomass dry weight $(\mathrm{mg} / \mathrm{mL})$.

\section{Partial purification of tannase}

Enzyme obtained from the culture filtrate and homogenized mycelia were precipitated with solid ammonium sulfate $\left(60-90 \%\right.$ saturation) at $4{ }^{\circ} \mathrm{C}$ for overnight. The precipitate was collected by centrifugation (15,000 x g, $15 \mathrm{~min})$, dissolved in citrate buffer ( $0.1 \mathrm{M}, \mathrm{pH} 5.0)$ and dialyzed against the same buffer for 2 days. The dialysates were used as the source of partially purified enzyme for the study of enzyme properties.

\section{Assay of tannase}

Tannase activity was determined by the method of Mondal and Pati ${ }^{11}$. Enzyme solution $(0.1$ $\mathrm{mL}$ ) was incubated with $0.3 \mathrm{~mL}$ of $1.0 \%(\mathrm{w} / \mathrm{v})$ tannic acid, in $0.2 \mathrm{M}$ acetate buffer $(\mathrm{pH} 5.0)$ at $40{ }^{\circ} \mathrm{C}$ for $30 \mathrm{~min}$ and then the reaction was terminated at $0{ }^{\circ} \mathrm{C}$ by the addition of $2 \mathrm{~mL}$ BSA $(1 \mathrm{mg} / \mathrm{mL})$, which precipitates the remaining tannic acid. A control reaction was also done side by side with heat denatured enzyme. The tubes were then centrifuged $(5,000 \mathrm{x} \mathrm{g}$, $10 \mathrm{~min})$ and the precipitate was dissolved in $2 \mathrm{~mL}$ of SDS - triethanolamine $(1 \% \mathrm{w} / \mathrm{v}$, triethanolamine) solution and the absorbency was measured at $550 \mathrm{~nm}$ after addition of $1 \mathrm{~mL}$ of $\mathrm{FeCl}_{3}(0.13 \mathrm{M})$.

One unit of the tannase was defined as the amount of enzyme, which is able to hydrolyse $1 \mu$ mole of ester linkage of tannic acid in $1 \mathrm{~min}$ at specific condition.

\section{Results and Discussion}

In the present work, studies on the tannase production from Aspergillus niger was carried out and the results were given in the Tables and Figs. The effect of some parameters at different ranges was studied and their influence on the production was discussed in this paper.

\section{Optimization of some parameters for maximum Tannase production}

\section{Effect of glucose conc. $(\% \mathrm{w} / \mathrm{v})$ on tannase production}

To study the effect of different glucose conc. on tannase production, the glucose concentration of the medium was varied from $0.01 \%$ to $1 \%(\mathrm{w} / \mathrm{v})$. It has been found that glucose at higher concentration repressed tannase synthesis while the lower concentration is not repressive. Maximum enzyme production occurred at $0.05 \%(\mathrm{w} / \mathrm{v})$ glucose, respectively in Tannic acid medium. Higher concentration of glucose repressed enzyme production due to the availability of ready made carbon source maximum tannase activity was $21.42 \mathrm{U} / \mathrm{mL}$ by Aspergillus niger after the optimum glucose concentration of $0.5 \%(\mathrm{w} / \mathrm{v})$. The obtained results were tabulated in Table 1 and also shown in Fig 1. Earlier Beverini et al. also mentioned that lower concentration of glucose is not repressive for enzyme production in A. Japonicas but its concentration above $1.0 \%$ is inhibitory for both growth and enzyme production ${ }^{12}$. 
Table 1. Effect of glucose concentration \% (w/v) on tannase production

\begin{tabular}{ccc}
\hline S.No. & $\begin{array}{c}\text { Glucose conc. } \\
(\%, \mathrm{w} / \mathrm{v})\end{array}$ & $\begin{array}{c}\text { Tannase activity } \\
(\mathrm{U} / \mathrm{mL})\end{array}$ \\
\hline 1. & 0.01 & 16.61 \\
2. & 0.05 & 19.22 \\
3. & 0.1 & 20.32 \\
4. & 0.5 & 21.42 \\
5. & 1 & 18.32 \\
6 & 1.5 & 17.24 \\
\hline
\end{tabular}

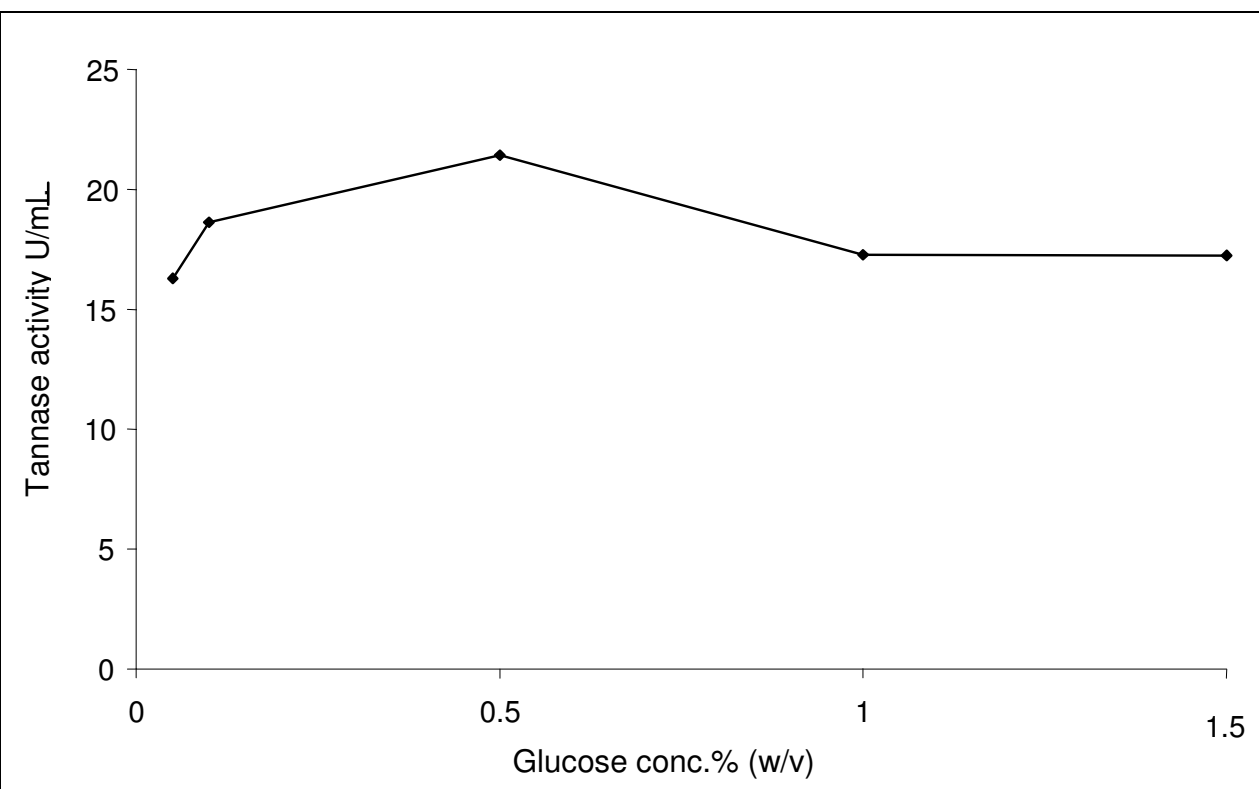

Figure 1. Effect of glucose concentration on tannase production

\section{Effect incubation period $(h)$ on tannase production}

To evaluate the effect of different incubation period on tannase production, the incubation period of the medium range was varied from $12 \mathrm{~h}$ to $72 \mathrm{~h}$. With a rise in incubation period, the tannase production increased and optimum activity was recorded at $36 \mathrm{~h}$ (Fig. 2). With a further increase in incubation period, there was a decrease in activity. Maximum tannase activity was $20.26 \mathrm{U} / \mathrm{mL}$ by the Aspergillus niger after the optimum incubation period of $36 \mathrm{~h}$. The obtained results were tabulated in Table 2 and also shown in Fig 2. An optimum incubation period around $36 \mathrm{~h}$ has been reported for tannase activity in case of A. aculeate D B F $9^{13}$. 
Table 2. Effect of incubation period on tannase production

\begin{tabular}{ccc}
\hline S.No. & $\begin{array}{c}\text { Incubation period, } \\
(\mathrm{h})\end{array}$ & $\begin{array}{c}\text { Tannase activity } \\
(\mathrm{U} / \mathrm{mL})\end{array}$ \\
\hline 1. & 12 & 12.62 \\
2. & 24 & 16.38 \\
3. & 36 & 20.26 \\
4. & 48 & 18.42 \\
5. & 60 & 14.83 \\
6. & 72 & 13.42 \\
\hline
\end{tabular}

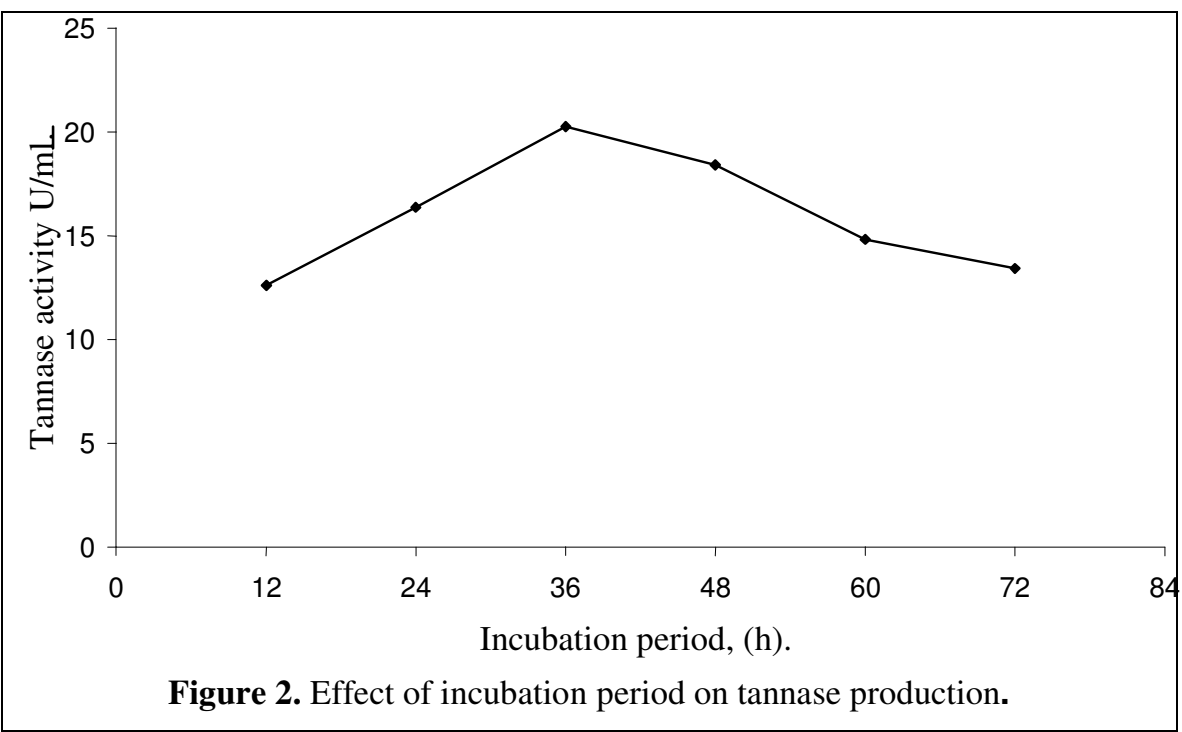

\section{Effect of $p H$ on tannase production}

To study the effect of initial $\mathrm{pH}$ on Tannase production, the $\mathrm{pH}$ of the medium was varied from $3.5-6.0$ using $1 \mathrm{~N} \mathrm{HCl}$ and $1 \mathrm{~N} \mathrm{NaOH}$, and fermentation was done as usual. The enzyme was active at acidic $\mathrm{pH}$ and activity decreased as the $\mathrm{pH}$ approached the alkaline range. The optimum tannase production was recorded at $\mathrm{pH} 5.5$ (Fig.3). Maximum tannase activity was $22.62 \mathrm{U} / \mathrm{mL}$ by the Aspergillus niger after the optimum $\mathrm{pH}$ of 5.5. Any change in $\mathrm{pH}$ affects the protein structure and a decline in enzyme in activation or its instability. It could be concluded from the results that tannase from the Aspergillus niger needed an acidic environment to be active. Fungal tannase is an acidic protein in general. The obtained results were tabulated in Table 3.and also shown in Fig 3. There are reports describing of the optimum $\mathrm{pH}$ as 5.5 in case of tannase obtained from A. oryzae ${ }^{14}$ and 6.0 in case of tannase obtained from P.chrysogenum and A. niger ${ }^{15}$. 
Table 3. Effect of $\mathrm{pH}$ on tannase production

\begin{tabular}{ccc}
\hline S.No & $\mathrm{pH}$ & Enzyme activity $(\mathrm{U} / \mathrm{mL})$ \\
\hline 1 & 3.5 & 14.32 \\
2 & 4 & 16.28 \\
3 & 4.5 & 18.64 \\
4 & 5 & 20.02 \\
5 & 5.5 & 22.62 \\
6 & 6 & 16.42 \\
\hline
\end{tabular}

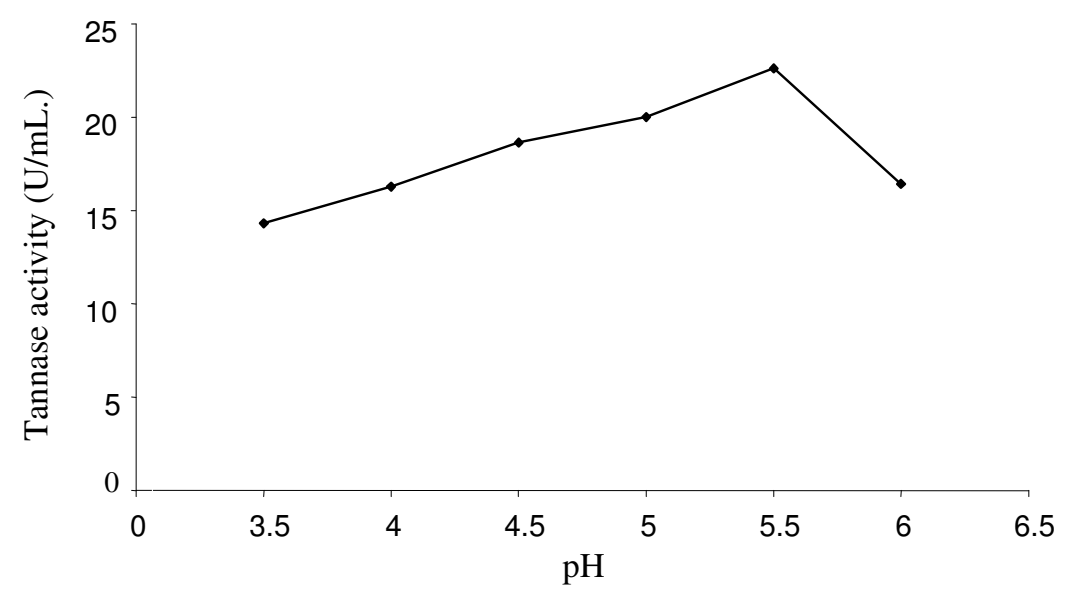

Figure 3. Effect of $\mathrm{pH}$ on tannase production

\section{Effect of temperature on tannase production}

To study the effect of different temperatures on tannase production, the flasks containing medium kept at temperature range was varied from $25-50{ }^{\circ} \mathrm{C}$. With a rise in temperature, the tannase production increased and optimum activity $23.52 \mathrm{U} / \mathrm{mL}$ was recorded at $35{ }^{\circ} \mathrm{C}$ (Fig.4). With a further increase in temperature, there was a decrease in activity. The optimum temperature for tannase production was $35^{\circ} \mathrm{C}$. The obtained results were tabulated in Table 4 and also shown in Fig 4. An optimum temperature around $30{ }^{\circ} \mathrm{C}$ has been reported for tannase activity in case of A. oryrae ${ }^{16}$ and P.chysogenum, around $35^{\circ} \mathrm{C}$ in case of A.niger and $50{ }^{\circ} \mathrm{C}$ in case of candida sp. ${ }^{17}$.

Table 4. Effect of temperature on tannase production

\begin{tabular}{ccc}
\hline S.No. & $\begin{array}{c}\text { Temperature } \\
\left({ }^{\circ} \mathrm{C}\right)\end{array}$ & $\begin{array}{c}\text { Tannase activity } \\
\mathrm{U} / \mathrm{mL}\end{array}$ \\
\hline 1. & 25 & 12.20 \\
2. & 30 & 16.52 \\
3. & 35 & 23.52 \\
4. & 40 & 18.48 \\
5. & 45 & 16.22 \\
6. & 50 & 15.43 \\
\hline
\end{tabular}




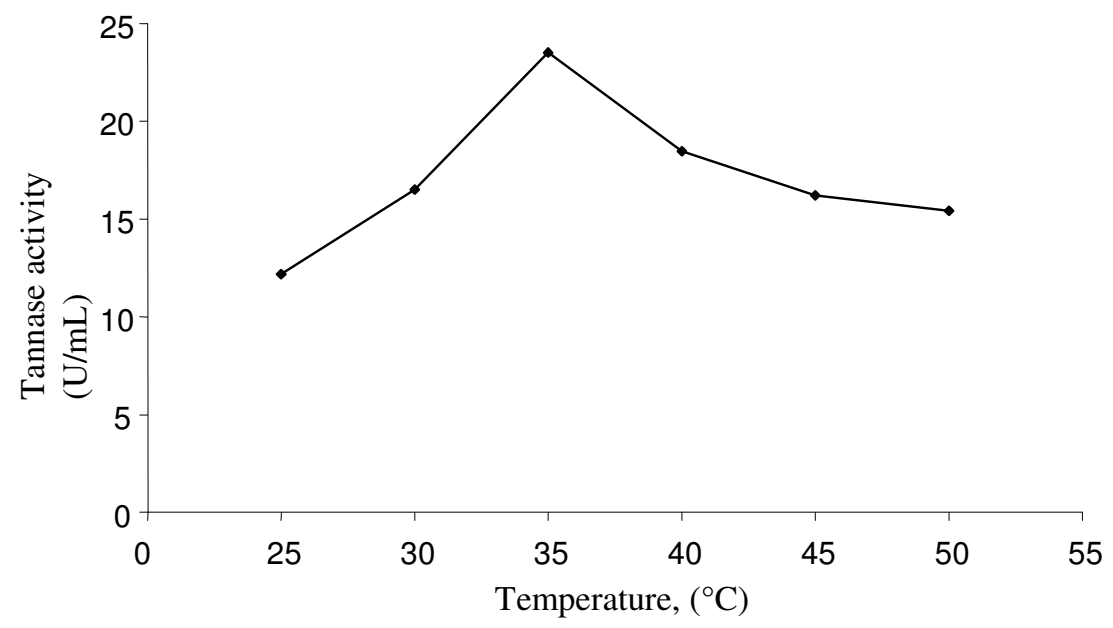

Figure 4. Effect of Temperature on tannase production

\section{Conclusions}

The present work has been taken up with a view of exploring the possibilities of using Aspergillus niger as a source for the production of tannase which can hydrolyse gallotannin to gallic acid. The high yields of tannase $(24.26 \mathrm{U} / \mathrm{mL})$ under optimum conditions show that the method is quite efficient and the tannase producing fungi Aspergillus niger gave high yield of tannase activity $65.8 \%$. This strain is able to produce tannase in the medium containing Tannic acid as the sole carbon source.

\section{References}

1. Iibuchi S, Minoda Y, and Yamada K, Agric. Biol. Chem, 1967, 32, 513 - 518.

2. Rajakumar G.S, and Nandy S.C, Appl. Enviorn. Microbiol, 1983, 46, 525 - 527.

3. Sitting M, In Pharmaceutical Manufacturing Encyclopedia, $2^{\text {nd }}$ (eds.). 1988, 282-.

4. Lekha P K, and LonsaneB K, Chem Microbiol;Technol Lebensm, 1993, 44, 215.

5. Lekha P K, and Lonsane B K, State of the art. Adv. Appl. Microbiol,1997, 44. 215.

6. Madhavakrishna W, Bose S M, and Nayudamma Y, 1960, Bull. CLRI 7, 1-11.

7. Jean D, Pourrat H, Pourrat A, and Carnat A, Anal. Biochem, 1981, 110, 369-372.

8. Niehaus J U, and Gross G G, Phytochemistry, 1997, 45, 1555 - 1560.

9. Inoue K H, and Hagerman A E, Anal. Biochem, 1988, 169,363 - 369

10. Skene I K, and Brooker J D Anaerobe, 1995, 1, 321-327.

11. Mondal K C, and Pati B R, J. Basic Microbiol, 2000, 40, 223-232

12. Beverini M, and Metche M, Sci Aliments 1990, 10, 807-16.

13. Lekha P K, and Lonsane, B K, Process Biochem, I994, 29, 497-503.

14. Yamada H, Adachi M, Watanabe M, and Sato N, Agric Biol Chem, 1968, 32(9), 1070.

15. Barthomeuf C, Regerat F, and Pourrat H, J. Ferment Bioeng, 1994, 77(3), 320-3.

16. Ibuchi S, Minoda Y, and Yamada K, Agric Biol chem. 1968, 32(7), 803- 809.

17. Aoki K, Shinke R, Nishira H, Agric Biol Chem 1976, 40(1), 79-85. 


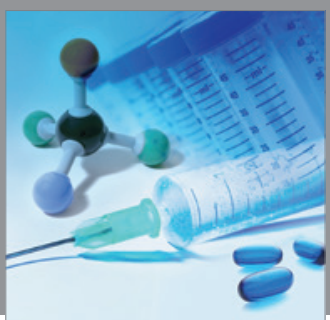

International Journal of

Medicinal Chemistry

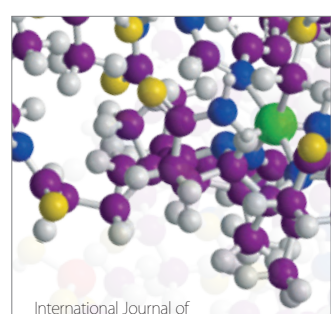

Carbohydrate Chemistry

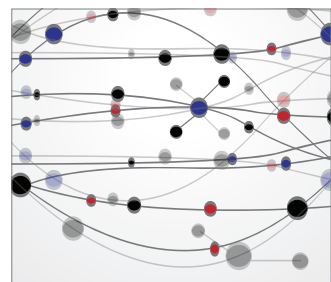

The Scientific World Journal
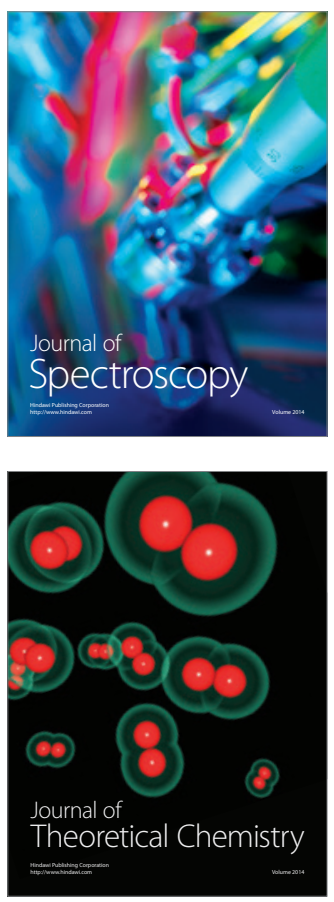
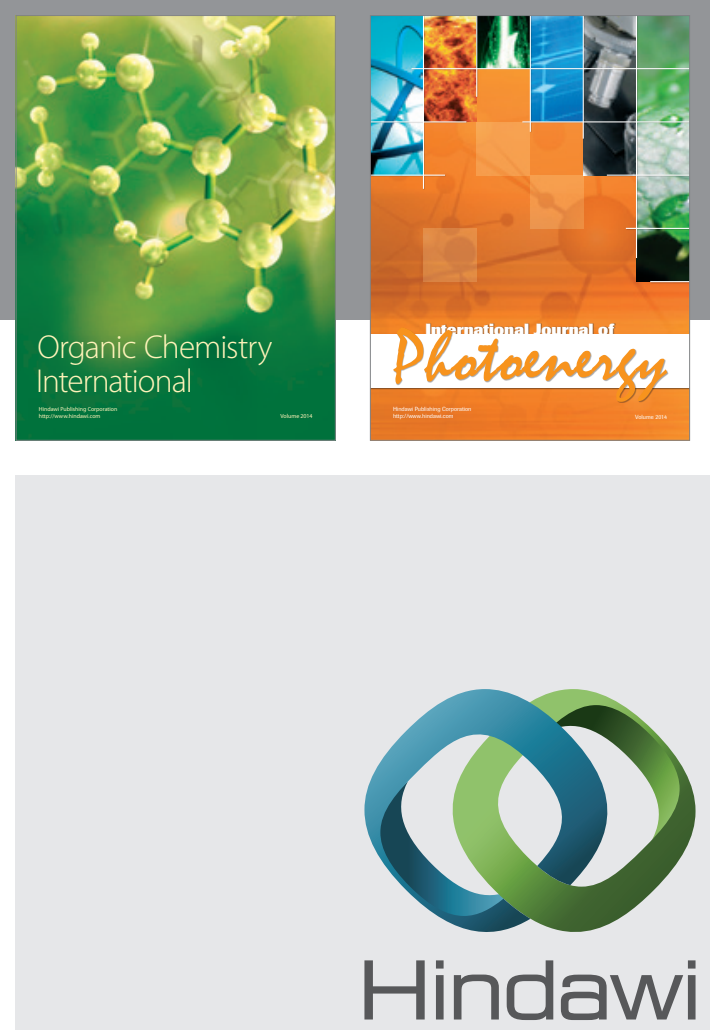

Submit your manuscripts at

http://www.hindawi.com
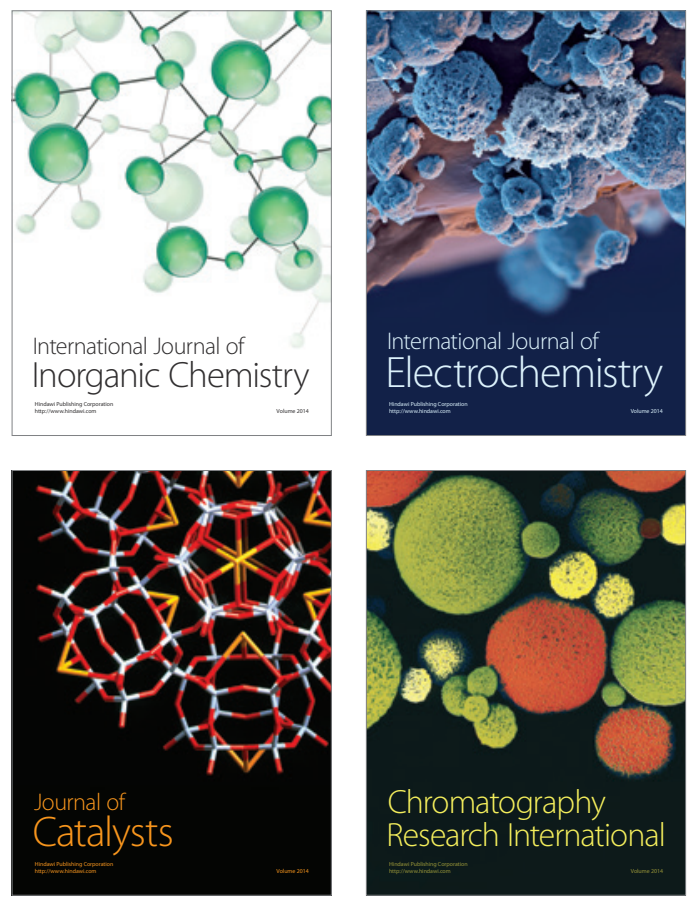
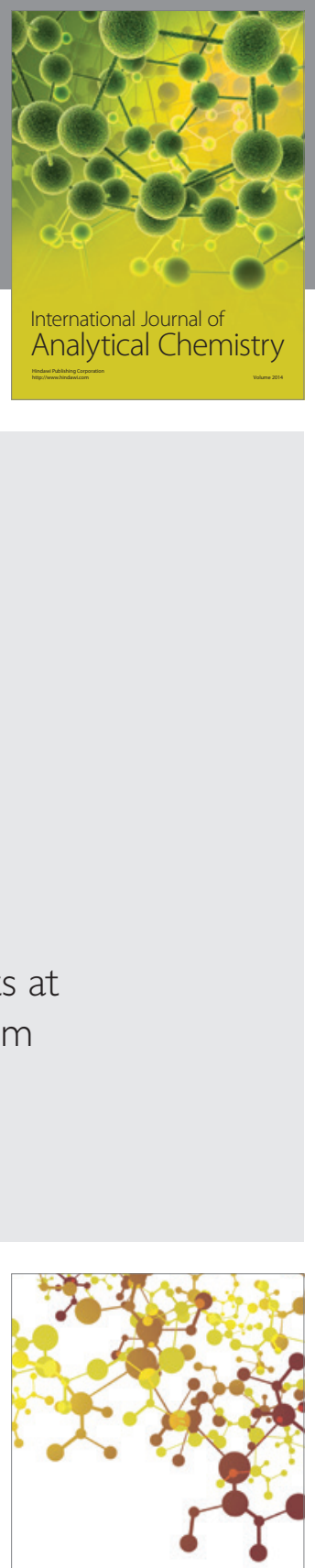

Journal of

Applied Chemistry
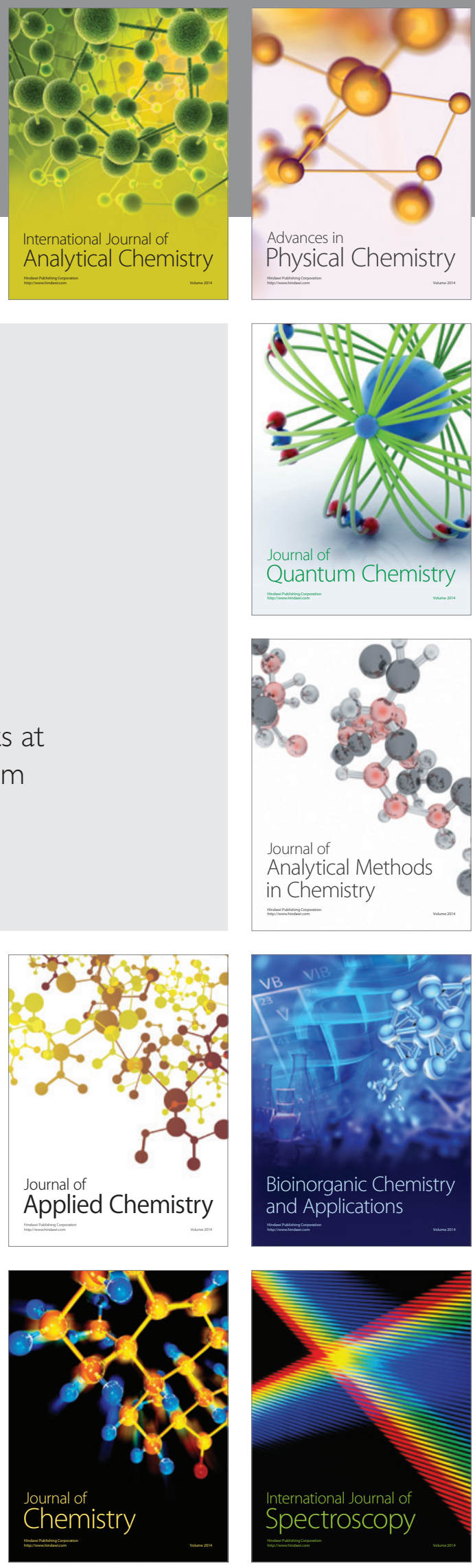